American Journal of Agricultural and Biological Sciences 6 (1): 105-109, 2011

ISSN 1557-4989

(C) 2010 Science Publications

\title{
Exploring Alternative Solutions Regarding Conservation Agriculture
}

\author{
Reza Movahedi, Hadi Fathi, Mousa Aazami and Somaye Latifi \\ Department of Agricultural Extension and Education, \\ College of Agriculture, Bu-Ali- Sina University- Hamedan, Iran
}

\begin{abstract}
Problem statement: Studies show that no effective measures have been taken towards conservative agriculture in Iran. Social, economical and technical agricultural factors and conditions need to be provided to meet conservation agriculture at the farm, regional and national level. Accordingly, this research aimed at exploring some solutions to protect and conserve agriculture. Approach: To achieve this, of all 100 populations, included both 80 faculty members of college of agriculture at Bu-Ali-Sina University and 20 subject matter specialists in Hamedan's State Agricultural Organization, 35 people were selected based on the criterion type of purposeful sampling. Data were gathered through interviews. Content analysis method was used to analyze textual data. Results: Results of this study showed that the building awareness and culture along with factors such as proper conservation agriculture practices, effective planning and management and attention to agro-ecological issues are basic factors to promote conservation agriculture in the surveyed area. Conclusions/Recommendations: Lack of awareness and knowledge of farmers and people towards conservation agriculture, no adoption of conservation agriculture by farmers and lack of education and training services for conservation agriculture were the most important issues that found in this research about conservation agriculture. Therefore, support the creating of cooperatives to provide necessary services for implementing conservation agriculture practices is definitely recommended.
\end{abstract}

Key words: Conservation Agriculture (CA), farmers, extension services, Hamedan province of Iran, European Conservation Agriculture Foundation (ECAF), pesticides, cooperatives, conventional rotations, Farmer Field Schools (FFS)

\section{INTRODUCTION}

Conservation Agriculture (CA) defined as minimal soil disturbance and permanent soil cover (Mulch) combined with rotations, is a recent agricultural management system that is gaining popularity in many parts of the world (Hobbs et al., 2008). The overall goal of conservation agriculture is to make better use of agricultural resources (than does conventional agriculture) through the integrated management of available soil, water and biological resources such that external inputs can be minimized (Awang and May, 2009; FAO, 2001; Garcia-Torres et al., 2003).

There are empirical investigations that show benefits and positive impacts of conservation agriculture at the farm and regional/national scales socially and financially (Knower, 2003; Nash et al., 2005; Stonehouse, 1997; Sorrenson et al., 2008). This is largely true because of reduced costs for machinery, fuel and labor, combined with unchanged or improved yields over time. Beyond the practice of conservation tillage alone, Knowler (2003) and Elobaid et al. (2009) show that a great number of soil conserving practices typically produce net financial benefits for adopters, over one hundred farm-level financial analyses from Sub-Saharan Africa and Latin America/Caribbean.

In Europe, findings by Lahmar (2010) revealed that cost savings in fuel, labor and machinery remain the most important economic feature of CA.

Extension access and NGO support (NGO) significantly influenced adoption of different components of conservation agriculture. Where government extension officers have been working closely with NGO staff in promoting the technology, they have become an important source of backup technical support (Mazvimavi and Twomlow, 2009).

According to Knowler and Bradshaw (2007) some of the benefits of conservation agriculture practices are:

Corresponding Author: Reza Movahedi, Department of Agricultural Extension and Education, Agricultural Education, College of Agriculture, Bu-Ali- Sina University, Hamedan, Iran

Tel: +98(811) 4424195 Fax: +98(811) 4424012 
increase in soil fertility and moisture retention, resulting in long-term, yield increase, decreasing yield variations and greater food security, reduction in on-farm costs, savings in time, labor and mechanized machinery, reduction in air pollution resulting from soil tillage machinery, application of additional herbicides and formation and operation of farmers' groups.

There are many factors affecting on developing conservation agriculture, including social, financial and agricultural technical factors. In terms of social, Knowler and Bradshaw (2007) showed that education, age, experience and sources of information have and affect on farmers' adoption of conservation agriculture. Among the many factors that reflect the financial conditions, farm size, land tenure, farm income, offfarm income and labor sources have taken into attention in studies of conservation agriculture. Owning to technical agriculture the factors like conservation tillage, use permanent or semi-permanent organic soil cover, extensive crop rotations and straw mulching and low- input sustainable practices are well known practices help farmers to maintain soil structure and productivity (Bagheri et al., 2008; ECAF, 1992; FAO, 2001; Mahdei, 2010).

While agriculture is one of the most important economic sectors in Iran, which comprises a considerably high percentage of production and employment (Movahedi, 2009), Iran's agriculture potential has not been met, as available resources have not been used properly. For instance, only $37 \%$ of cultivable land and $58 \%$ of acquirable water are currently being utilized. In addition, sustainable land and water use has not yet been achieved. Although there is growing concern about the conservation agriculture in many regions of the world, there are no effective majors towards conservation agriculture in Iran. Therefore, social, economic and technical agricultural factors and conditions need to be provided to meet conservation agriculture at the farm, regional and national level. Accordingly, this research aimed at exploring some alternative efforts to promote and develop conservation agriculture.

Purposes and objectives: The purpose of this study was to improve and develop conservation agriculture activities. The objectives of the study were:

- Identifying efforts and solutions to promote and improve conservation agriculture

- Determining appropriate Conservation agriculture practices and

- Introducing problems and constraints involved in conservation agriculture activities

\section{METERIALS AND METHODS}

Statistical population of the study included both 80 faculty members of college of agriculture at Bu-AliSina University and 20 subject matter specialists who were working in Hamedan's State Agricultural Organization. Of all 100 populations, 35 people were selected based on the criterion type of purposeful sampling. Purposeful sampling is an approach that assists the researcher in selecting intentionally specific places, people and phenomena, each of which bear significance in information gathering (Maxwell 2005). Criterion sampling is one of the types of purposeful sampling in which the samples are selected based on specific criterion and standards (Patton, 1990). Both having experience (and being closely related to the studied phenomenon are the main criteria for selecting samples in qualitative research; therefore, the employees used in this research study were selected based on experience and close relations to conservation agriculture activities.

Data were gathered through interviews. Interviewing methods as qualitative research have great potential to explore complex situations involving people's constructions of meanings and are therefore appropriate for incremental improvements in understanding (Kirk and Miller, 1986).

While a structured interview has a formalized and limited set of questions, a semi-structured interview method, selected in this study, is more flexible, allowing new questions to be brought up during the interview. According to Flick (2002), semi-structured questions are either oriented to the scientific literature about a given topic (theory driven) or are based on the researcher's theoretical presumptions (hypothesis directed). In this study, semi-structured interviews were developed through different interview guides were constructed in order to collect data from two groups of participants, agricultural experts and faculty members in Bu-Ali-Sina University. During the face-to-face interview process, all of the data was recorded by an mp3 set. Notes also were taken.

Content analysis method was used to analyze textual data. Content analysis is a qualitative analysis method that enables the researcher to include large amounts of textual information and identify its properties systematically, e.g. the frequencies of most used Key Words in Context (KWIC) by detecting the most important structures of its communication content (Neuendorf, 2002). In this technique, items with the same concepts and ideas are reduced (first reduction) and common ideas are summarized and categorized (second reduction). The main idea of this technique is 
Am. J. Agri. \& Biol. Sci., 6 (1): 105-109, 2011

the reduction and summarization of the text (Flick 2002).

\section{RESULTS AND DISCUSSION}

Efforts and solutions for improving conservation agriculture: The respondents were asked during the interview process about efforts and solutions for improving conservation agriculture.

After reviewing the responses using the content analysis method, summarized results were emerged into common themes as in Table 1. Using proper agricultural practices, building awareness and culture have been proposed by respondents as the most important solutions to improve conservation agriculture status. Some comments of interviewees are given as below:

Human factor is the most important factor (without understanding the technology is not efficient), we need to have a Culture of Human Resources Management. So, before anything education and training should be offered about agricultural conservation through public media for all the stakeholders. Make people and farmers aware of the benefits of conservation agricultural and harmful effects of chemicals and fertilizers has an important role. This should be done by help of extension and education services.

According to one of the interviewee's opinion "people good thinking, management thinking of the state, shifting to private sector, macro-level support and policy and creating powerful cooperatives with government's support are of required factors to achieve agricultural improvement. Another respondent added that "management of agricultural machinery and implements, water and soil management, integrated pest and diseases management, advisory services and monitoring of farmers practices and creating cooperatives to gain benefit necessary services all with a significant strategy bring conservation agriculture into best situation.

Focus on eco- friendly methods including sustainable agriculture and organic agriculture was of alternatives mentioned by some of the respondents. For instance, one of them said: "environmental imbalanced is occurred by human intervention through using contaminants like pesticides and fertilizers.
Table 1: Efforts and solutions for improving conservation agriculture

\begin{tabular}{lll}
\hline Themes & Frequency & Percent \\
\hline $\begin{array}{l}\text { Agricultural proper practices } \\
\text { Building awareness } \\
\text { culture and education }\end{array}$ & 10 & 29 \\
$\begin{array}{l}\text { Management and planning } \\
\begin{array}{l}\text { Environmental methods } \\
\text { (organic farming, sustainable }\end{array}\end{array}$ & 7 & 20 \\
$\begin{array}{l}\text { agriculture) } \\
\begin{array}{l}\text { New technology } \\
\text { (precision agriculture, }\end{array}\end{array}$ & 5 & 14 \\
$\begin{array}{l}\text { ICT, Internet) } \\
\begin{array}{l}\text { Supportive policy of the state } \\
\text { Applied research }\end{array}\end{array}$ & 2 & 14 \\
\hline
\end{tabular}

Table 2: Conservation agriculture practices

\begin{tabular}{lll}
\hline Themes & Frequency & Percent \\
\hline Crop rotation & 7 & 20 \\
Mixed farming & 6 & 17 \\
Low-input practices & 5 & 14 \\
Biological control methods & 5 & 14 \\
Permanent covering by mulching soil & 4 & 11 \\
No tillage & 3 & 9 \\
Water optimum use & 3 & 9 \\
Conservation plowing & 2 & 6 \\
\hline
\end{tabular}

Table 3: Conservation agriculture's problems and constraints

\begin{tabular}{llc}
\hline Themes & Frequency & Percent \\
\hline $\begin{array}{l}\text { Lack of awareness and knowledge } \\
\text { towards conservation agriculture }\end{array}$ & 8 & 23 \\
$\begin{array}{l}\text { Non- adoption of conservation } \\
\text { agriculture due to gaining }\end{array}$ & 7 & 20 \\
$\begin{array}{l}\text { short-term benefits } \\
\begin{array}{l}\text { Lack of training about appropriate } \\
\text { use of resources and inputs }\end{array}\end{array}$ & 7 & 20 \\
$\begin{array}{l}\text { No legislations and state supports } \\
\text { No monitoring and control on }\end{array}$ & 5 & 14 \\
$\begin{array}{l}\text { agricultural practices } \\
\text { Gap between academic } \\
\text { centers and farmers }\end{array}$ & 4 & 11 \\
$\begin{array}{l}\text { Lack of knowledge to } \\
\text { new agricultural issues }\end{array}$ & 2 & 11 \\
\hline
\end{tabular}

Using pesticides that are common among farmers, however, will cause early performance, will load many long-term consequences". Therefore, emphasis on ecofriendly methods like sustainable agriculture and organic farming must be more attention than before.

Conservation agriculture practices: The respondents were asked to explain their ideas about conservation agriculture practices. After content analyzing of respondents' ideas, the practices including crop rotation, mixed methods of farming, low-input practices and biological control of pests and diseases were categorized into the themes by the highest frequency. Results have given into Table 2 .

The faculty members and agriculture experts were asked about problems and constraints facing conservation agriculture. Lack awareness and knowledge towards conservation agriculture, non- 
adoption of conservation agriculture due to gaining short-term benefits, lack of training about appropriate use of resources and inputs were the most problems engaged to conservation agriculture (Table 3).

Some comments of respondents about conservation agriculture's problems have directly quoted below:

Most of the major reasons for not using conservation agriculture practices are lack of understanding and awareness to CA and lack of understanding towards proper use of agricultural resources and inputs. This is due to low knowledge of farmers to agricultural day sciences. Student Most farmers have low level education so that only 4 percent of farmers in Iran have a college education that this rate is low. Therefore, strengthening training infrastructure for farmers is essential.

"I think the dominant agricultural system in Iran is small-scale farming and farmers have accustomed to conventional cultivation methods, so adoption new farm practices are difficult for them. To solve this problem, the state should support conservation agriculture through creating cooperatives, financial and legislation protection".

"Considering this point that conservation agriculture practices have long-term profits, the farmers have low trend to adopt these practices. The farmers are almost looking for more and short-term economic benefits. Therefore, majors should be proposed to provide economic interests of farmers who are interesting to apply conservation agriculture practices".

\section{CONCLUSION}

Reviewing on conservation agriculture development in the world shows that many factors are involved in this concern. Among the social factors education, building awareness and culture among farmers and people have a determining role in the world. Results of this study showed that the mentioned factor along with factors such as proper conservation agriculture practices, effective planning and management and attention to agro-ecological issues are basic factors to promote conservation agriculture in the surveyed area.

There are well-known and empirical tested conservation agriculture practices in the world. Among these practices, conservation tillage, use permanent or semi-permanent organic soil cover, crop rotations, straw mulching and low- input practices are practices acceptable and approved by FAO and European Conservation Agriculture Foundation (ECAF). This study also showed that practices such as crop rotation, mixed cultures, low-input usage in particular use of fertilizer and pesticides, No tillage or conservation tillage and the use of permanent mulch cover are the most suitable conservation agriculture practices, respectively.

Regardless special support policies and plans have been paid to conservation agriculture in the world currently, but in our country there are many problems and constraints faced to promote and develop conservation agriculture. Lack of awareness and knowledge of farmers and people towards conservation agriculture, no adoption of conservation agriculture by farmers and lack of education and training services for conservation agriculture were the most important issues that found in this research about conservation agriculture. Considering the emphasis of conservation agriculture on using low-input practices, no-tillage and crop rotation to prevent soil structure and quality, these all are not profitable for farmers who look for shortterm interests. Therefore is it apparent that the farmers will not adopt the conservation agriculture. In this regard, the supportive role of government, private sector and NGOs is very imperative. For example, the state can use a policy of removing fertilizer and pesticide subsidies and support conservation agriculture practices instead of it. Also, the state can play an effective role by addressing extension and education services about conservation agriculture for both farmers and people through encouraging participation of private sector, NGOs and public media. This also is implied by findings of Mazvimavi and Twomlow (2009). Eventually, support the creating of cooperatives to provide necessary services for implementing conservation agriculture practices is definitely recommended.

From the results of this research, the following recommendations are drawn:

- Expanding culture-building among farmers and people about conservation agriculture through extension and education services and media

- Informing and building awareness farmers and people towards the harmful effects of fertilizers and pesticides through various media with the support of government

- Promoting the use of integrated pest management and biological control methods

- Eliminating government subsidies for chemical pesticides and avoiding chemical contaminants by laws and instead support the biological control and conservation agriculture

- Linking between government and research centers for providing facilities necessary for activities related to conservation agriculture 
- Support for applied research in conservation agriculture and sustainable agriculture

- Upgrading level of education and training of farmers using the Farmer Field Schools (FFS) by help of advisory private sectors

- Determining a legal status for conservation agricultural and sustainable agriculture

\section{REFERENCES}

Awang, R. and C.Y. May, 2009. Charcoal-oil mixture as an alternative fuel: A preliminary study. Am. J. Applied Sci., 6: 393-395. DOI: 10.3844/ajassp.2009.393.395

Bagheri, A., H.S. Fami, A. Rezvanfar, A. Asadi and S. Yazdani, 2008. Perceptions of paddy farmers towards sustainable agricultural technologies: case of haraz catchments area in mazandaran province of Iran. Am. J. Applied Sci., 5: 1384-1391. DOI: 10.3844/ajassp.2008.1384.1391

ECAF, 1992. Conservation agriculture in Europe: environmental, economic and EU policy perspectives. 1st Edn., European Conservation Agriculture Federation, UK., pp: 23.

Elobaid, R.M., M. Shitan, N.A. Ibrahim, A.N.A. Ghani and Daud, 2009. Evolution of spatial correlation of mean diameter: a case study of trees in natural dipterocarp forest. J. Math. Stat., 5: 267-269. DOI: 10.3844/jmssp.2009.267.269

FAO, 2001. The Economics of Soil Productivity in Africa. 1st Edn., Food and Agriculture Organization of the U, USA., pp: 66.

Flick, U., 2002. An introduction to qualitative research. 4th Edn., Sage publications, USA., pp: 528.

Garcia-Torres, L., J. Benites, A. Martinez-Vilela and A. Holgado-Cabrera, 2003. 1st Edn., Conservation Agriculture: Environment, Farmers Experiences, Innovations, Socio-economy, Policy. Springer, USA., pp: 516.

Hobbs, P.R., K. Sayre and R. Gupta, 2008. The role of conservation agriculture in sustainable agriculture. Philosophical Trans. Royal Soc., 363: 543-555. DOI: 10.1098/rstb.2007.2169

Kirk, J. and M.L. Miller, 1986. Reliability and Validity in qualitative Research. 1st Edn., Sage Publications, USA., pp: 23.

Knowler, D. and B. Bradshaw, 2007. Farmers' adoption of conservation agriculture: A review and synthesis of recent research. Food Policy, 32: 25-48. DOI: 10.1016/j.foodpol.2006.01.003
Knowler, D.J., 2003. Explaining the financial attractiveness of soil and water conservation -a meta-analysis model. Proceeding of the 2003 Soil and Water Conservation Society's Annual Conference, July 26-30, Spokane, Washington.

Lahmar, R., 2010. Adoption of conservation agriculture in Europe lessons of the KASSA project. Land Use Policy, 27: 4-10. http://publications.cirad.fr/une_notice.php?dk=552507

Mahdei, K.N., S.M. Hosseini, M. Aazami and H. Saadi, 2010. Administrative feasibility of monitoring mechanisms implementation for sustainable agriculture. Am. J. Applied Sci., 7: 208-213. DOI: 10.3844/ajassp.2010.208.213

Maxwell, J.A., 2005. Qualitative Research Design: An Interactive Approach. 2nd Edn., Sage Publications, USA., pp: 174.

Mazvimavi, K and S. Twomlow, 2009. Socioeconomic and institutional factors influencing adoption of conservation farming by vulnerable households in Zimbabwe. Agric. Syst., 101: 20-29. http://ideas.repec.org/a/eee/agisys/v101y2009i12p20-29.html

Movahedi, R., 2009. Competencies Needed by Agricultural Extension and Education Undergraduates for Employment in the Iranian Labor Market. 1st Edn., Dessertation.de, Berlin, pp: 6.

Nash, M.S., D.J. Chaloud, S.E. Franson, 2005. Association of landscape metrics to surface water biology in the savannah river Basin. J. Math. Stat., 1: 29-34. DOI: 10.3844/jmssp.2005.29.34

Neuendorf, K.A., 2002. The Content Analysis Guidebook. 1st Edn., Sage Publications, USA., pp: 301.

Patton, M.Q., 1990. Qualitative Evaluation and Research Methods, 2nd Ed., Sage, Publications, USA., pp: 532.

Sorrenson, W.J., C. Duarte and J. Lopez Portillo, 1998. Economics of no-till compared to conventional cultivation systems on small farms in Paraguay: policy and investment implications. Soil Conservation Project MAG-GTZ. http://www.rolfderpsch.com/notill.htm

Stonehouse, D.P., 1997. Socio-economics of alternative tillage systems. Soil Tillage Res., 43: 109-130.

DOI: 10.1016/S0167-1987(97)00037-8 